\title{
ANALISIS PEMECAHAN MASALAH KONTEKSTUAL DITINJAU DARI GAYA BELAJAR SISWA PADA MATERI ARITMATIKA SOSIAL
}

\author{
Asrar Mufida Masdy ${ }^{1}$, Suaedi ${ }^{2}$, Ma'rufi ${ }^{3}$ \\ Universitas Cokroaminoto Palopo ${ }^{123}$ \\ Email: asrarmufidam@gmail.com ${ }^{1}$, suadif@gmail.com², marufi.lyas@gmail.com³
}

\begin{abstract}
Abstrak. Penelitian ini bertujuan untuk mendeskripsikan hasil analisis kemampuan pemecahan masalah kontekstual ditinjau dari gaya belajar siswa pada materi aritmatika sosial. Analisis kemampuan pemecahan masalah menggunakan tahapan Polya yaitu (1) memahami masalah, (2) membuat rencana pemecahan masalah, (3) melaksanakan rencana pemecahan masalah, (4) memeriksa kembali pemecahan masalah. Subjek penelitian terdiri dari 3 siswa yang telah dikelompokkan berdasarkan gaya belajar visual, gaya belajar auditori, gaya belajar kinestetik. Penelitian ini dilaksanakan di SMPN 6 Palopo. Jenis penelitian ini adalah penelitian kualitatif deskriptif. Instrumen yang digunakan yaitu angket gaya belajar, tes kemampuan pemecahan masalah, dan pedoman wawancara. Berdasarkan hasil analisis data dapat disimpulkan bahwa: 1) Subjek dengan gaya belajar visual mampu memahami masalah, membuat rencana pemecahan masalah dengan baik, kurang teliti dalam melaksanakan rencana pemecahan masalah, dan melakukan pemeriksaan kembali jawaban akhir. (2) Subjek dengan gaya belajar auditori mampu memahami masalah dengan baik, membuat rencana penyelesaian dengan benar, dan melaksanakan rencana penyelesaian masalah dengan tepat serta memeriksa kembali hasil akhir. (3) subjek dengan gaya belajar kinestetik kurang mampu dalam memahami masalah, tidak dapat merencanakan penyelesaian masalah dengan baik, tidak dapat menyelesaikan rencana penyelesaian dikarenakan subjek kurang mampu dalam melakukan operasi hitung matematika sesuai dengan rumus yang digunakan utamanya perkalian dan pembagian, subjek tidak memeriksa kembali hasil akhir.
\end{abstract}

\section{Kata kunci: Kemampuan Pemecahan Masalah, Gaya belajar}

\begin{abstract}
This study aims to describe the results of the analysis of contextual problem-solving abilities in terms of student learning styles on social arithmetic material. Analysis of problem-solving abilities using Polya's stages, namely (1) understanding the problem, (2) making a problem-solving plan, (3) implementing a problem-solving plan, (4) re-examining problem solving. The research subjects consisted of 3 students who were grouped based on visual learning styles, auditory learning styles, and kinesthetic learning styles. This research was conducted at SMPN 6 Palopo. This type of research is descriptive qualitative research. The instruments used were learning style questionnaires, problem-solving ability tests, and interview guides. Based on the results of data analysis, it can be concluded that: 1) Subjects with a visual learning style are able to understand problems, plan problem solving well, less thorough in carrying out the problem-solving plan, and re-examine the final answer, while in the final stage the subject re-checks the final answers. (2) Subjects with an auditory learning style are able to understand the problem well, make a correct resolution plan, and carry out the problem-solving plan appropriately and reexamine the final result. (3) the subject with the kinesthetic learning style is less able to understand problems, cannot plan problem solving properly, cannot complete the completion plan because the subject is less capable of performing mathematical calculation operations in accordance with the formulas used mainly multiplication and division, the subject does not re-check the final result.
\end{abstract}

\section{Keywords: Problem Solving Ability, Learning Style}

\section{A. Pendahuluan}

Matematika adalah salah satu komponen dari serangkaian mata pelajaran yang penting dalam dunia pendidikan. Matematika juga sebagai bidang studi yang mendukung perkembangan ilmu pengetahuan dan teknologi. Pembelajaran matematika, diharapkan dapat memberikan konstribusi positif untuk tercapainya masyarakat yang cerdas dan bermartabat melalui cara bernalar dan berpikir secara logis, analitis, kritis, kreatif dan dapat bekerja sama. Menurut Trianto (2016), dengan belajar matematika siswa diharapkan mampu memecahkan 
masalah yang dihadapi, baik masalah dalam pelajaran matematika maupun masalah yang berkaitan dengan kehidupan sehari-hari.

Masalah matematika yang dihadapi siswa disebabhkan karena kurangnya algoritma pemecahan masalah. Pemecahan masalah matematika merupakan usaha yang dilakukan oleh seseorang dalam menggunakan konsep, sifat, prinsip, teorema, dan dalil matematika untuk menemukan penyelesaian dari masalah matematika (Ma'rufi dan Yulianti, 2019). Pemecahan masalah matematika merupakan usaha yang direncanakan seseorang untuk memperoleh penyelesaian dari masalah matematika. Proses perencanaan pemecahan masalah meliputi metode yang digunakan, prosedur, dan strategi dalam menyelesaikan masalah matematika berdasarkan kemampuan yang dimiliki. Sebagaimana pendapat Santia (2015) bahwa kemampuan pemecahan masalah merupakan kemampuan menyelesaikan masalah dengan mengaplikasikan pengetahuan, keterampilan serta pemahaman yang dimiliki siswa.

Menurut Polya (Santia, 2015) pemecahan masalah merupakan usaha untuk mencari jalan keluar dari suatu kesulitan untuk mencapai tujuan yang tidak segera dapat tercapai. Pemecahan masalah dalam matematika merupakan pemahaman kognitif menguraikan dan menjelaskan ide atau informasi yang dimiliki seseorang melalui proses berfikir. Menurut Polya (Santia, 2015), ada empat tahap pemecahan masalah yaitu memahami masalah, merencanakan penyelesaian masalah, melakukan perencanaan masalah, dan melihat kembali hasil yang diperoleh.

Menurut Trianto (2016) pembelajaran kontekstual merupakan konsep belajar yang membantu guru mengaitkan materi yang diajarkan dengan situasi dunia nyata. Pembelajaran kontekstual menhubungkan pengetahuan siswa dengan penerapannya dalam kehidupan seharui-hari. Berdasarkan pengalaman dan pengamatan peneliti sebagai pendidik selama ini, pembelajaran matematika di sekolah, masih menggunakan pendekatan konvensional. Pembelajaran di kelas dilaksanakan dengan urutan penjelaskan materi, pemberian contohcontoh soal dan pembahasanya, kemudian pemberian soal latihan dalam bentuk soal cerita..

Soal cerita merupakan soal yang sulit dipahami atau diselesaikan oleh sebagian besar siswa. Siswa merasa kesulitan dalam memahami masalah dalam soal cerita dan menafsirkan ke dalam kalimat matematika. Menurut Sugondo (Minarti \& Kusrini, 2012) soal cerita matematika merupakan soal-soal matematika yang menggunakan bahasa verbal dan umumnya berhubungan dengan kegiatan sehari-hari.

Di dalam kehidupan sehari-hari, sering digunakan perhitungan matematika dalam melakukan suatu kegiatan jual beli atau perdagangan. Dalam dunia perdagangan dikenal istilah untung dan rugi. Aritmatika sosial adalah bagian dari matematika yang membahas perhitungan keuangan dalam perdagangan dan kehidupan sehari-hari beserta aspek-aspeknya (Paramitha, 2017). Aritmatika sosial mencakup materi dalam kehidupan yaitu menentukan tara, bruto, netto, harga jual, harga beli, untung, rugi, diskon, nilai keseluruhan dan nilai per unit.

Siswa merupakan individual yang unik artinya tidak ada dua orang siswa yang sama persis. Setiap siswa memiliki perbedaan antara yang satu dengan yang lain dalam aspek fisik, pola pikir, dan cara merespons atau mempelajari sesuatu yang baru (Asrori, 2007). Perbedaan individual ini berpengaruh pada cara, gaya dan hasil belajar siswa. Gaya belajar merupakan cara siswa memahami pelajaran di sekolah. Gaya belajar yang dimiliki siswa dalam satu kelas tidak sama. Hal ini berakibat pada siswa yang satu dengan yang lain mempunyai gaya yang berbeda dalam mempelajari suatu materi pelajaran.

Pada umumnya, siswa memiliki gaya belajar yang berbeda-beda. Namun setiap siswa memiliki salah satu gaya belajar yang dominan, meskipun terdapat kemungkinan setiap siswa memiliki gaya belajar lainnya. De Porter dan Hernacki (2013) dalam Quantum Learning menyebutkan bahwa gaya belajar secara umum dapat dilihat dari modalitas dan dominasi otak. Menurut De Porter \& Hernacki (2013) terdapat tiga gaya belajar seseorang yaitu gaya belajar visual, auditori, dan kinestetik. Gaya belajar auditori adalah belajar dengan cara mendengar. Sedangkan gaya belajar kinestetik adalah belajar dengan cara bergerak, bekerja, dan menyentuh 
Pada dasarnya masing-masing siswa menggunakan ketiga gaya belajar ini, namun kebanyakan siswa lebih cenderung pada salah satu diantara gaya belajar tersebut. Litzinger dan Osif (Alisa, 2016) mendeskripsikan gaya belajar sebagai perbedaan cara yang digunakan oleh anak-anak dan orang dewasa dalam berpikir dan belajar.

Kemampuan pemecahan masalah kontekstual yang belum dikuasai siswa perlu dikaji lebih lanjut untuk mengetahui kemampuan pemecahan masalah siswa berdasarkan gaya belajar yang dimilikinya.. Hal ini sesuai dengan pendapat (Sanjaya, 2013) bahwa dalam proses pembelajaran kontekstual, guru perlu memahami gaya belajar siswa, dan menyesuaikan gaya mengajar sesuai dengan gaya belajar yang dimiliki siswa.

Berdasarkan studi pendahuluan pada hari Kamis tanggal 5 Desember 2019, yang dilakukan peneliti pada 29 siswa kelas VII semester ganjil yang telah mempelajari materi prasyarat aritmatika sosial yaitu materi aljabar. Hal ini terlihat dari indikator pemecahan masalah berdasarkan Polya yang muncul dari jawaban siswa pada tes awal yang diberikan adalah memahami masalah dan melaksanakan rencana penyelesaian masalah, namun dari hasil jawaban siswa tersebut masih belum tepat dan langkah penyelesaiannya tidak berurutan. Sedangkan indikator yang belum terlihat adalah menyusun rencana penyelesaian dan melakukan pengecekan kembali.

Untuk mengetahui indikator yang belum terlihat, maka peneliti melakukan penelitian dengan judul "Analisis Pemecahan Masalah Kontekstual Pada Materi Aritmatika Sosial Ditinjau Dari Gaya Belajar Siswa SMPN 6 Palopo". Dalam penelitian ini peneliti mengambil sampel siswa kelas 7 SMPN 6 Palopo.

\section{B. Metode Penelitian}

Penelitian ini merupakan jenis penelitian kualitatif dengan pendekatan analisis deskriptif atau dinamakan penelitian deskriptif kualitatif. Penelitian ini menggunakan pendekatan kualitatif dengan harapan agar dapat mendeskripsikan secara cermat kemampuan yang dimiliki siswa dalam pemecahan masalah Aritmatika Sosial ditinjau dari gaya belajar VAK (visual, auditori, kinestetik).

Lokasi penelitian ini di SMP Negeri 6 Palopo yang terletak di Jl. Pongsimpin Kota Palopo, Provinsi Sulawesi Selatan. Waktu penelitian ini dilaksanakan pada semester genap tahun ajaran 2019/2020. Subjek penelitian ini, terdiri dari tiga subjek penelitian yaitu siswa yang memiliki gaya belajar visual sebanyak 1 orang, gaya belajar auditori sebanyak 1 orang, dan gaya belajar kinestetik sebanyak 1 orang. Subjek-subjek yang dipilih diberikan tes pemecahan masalah aritmatika sosial untuk mengetahui kemampuan pemecahan masalah.

Proses pemilihan subjek dengan cara menetapkan kriteria pemilihan subjek melalui angket gaya belajar. Subjek yang memenuhi kriteria pemilihan akan diberikan soal pemecahan masalah kontekstual kemudian dianalisis kemampuan pemecahan masalah subjek, dan melakukan wawancara. Setelah diperoleh hasil wawancara dilakukan triangulasi waktu yaitu dengan membandingkan data subjek secara tertulis dari hasil metode tes dan data dari hasil wawancara sebanyak n-kali ( $\mathrm{n}$ adalah jumlah hingga memenuhi indikator penalaran yang dibutuhkan). Hasil triangulasi data yang sama merupakan data hasil penelitian subjek yang valid. Sedangkan data hasil penelitian yang berbeda akan dilakukan reduksi data atau dijadikan temuan penelitian ini.

Setelah memperoleh data valid, dibuat transkip hasil wawancara, disajikan data hasil tes dan transkip wawancara, mendeskripsikan kemampuan pemecahan masalah yang dimiliki subjek penelitian, menarik kesimpulan mengenai pemecahan masalah siswa dalam menyelesaikan soal pemecahan masalah kontekstual materi aritmatika sosial. Instrumen yang digunakan dalam penelitian ini terbagi 2 yaitu instrumen utama (peneliti sendiri) dan instrumen pendukung. 
Instrumen pendukung dalam penelitian ini, terdiri dari angket gaya belajar, tes pemecahan masalah kontekstual dan pedoman wawancara. Angket gaya belajar terdiri dari 42 pertanyaan. Pertanyaan nomor 1-14 merupakan kategori gaya belajar visual, pertanyaan nomor 15-28 kategori gaya belajar auditori, Sedangkan pertanyaan nomor 29-42 kategori gaya belajar kinestetik. Instrumen tes pemecahan masalah adalah soal uraian sebanyak 2 nomor yang dikerjakan secara individu dalam waktu 60 menit. Tes pemecahan masalah menggunakan tahapan pemecahan masalah Polya untuk mengetahui kemampuan pemecahan masalah matematika siswa. Pedoman wawancara dibuat dengan melihat respon siswa terhadap tes yang diberikan. Hal ini dilakukan dengan tujuan memperoleh data secara mendalam tentang kemampuan pemecahan masalah matematika siswa dalam menyelesaikan masalah aritmatika sosial, yang tidak dapat dideteksi dengan menggunakan tes pemecahan masalah kontekstual. Pertanyaan dalam instrumen dikembangkan hanya pada pertanyaan yang meminta subjek menjelaskan prosedur dalam penyelesaian tes pemecahan masalah aritmatika sosial sesuai dengan pemahamannya dengan menggunakan kata-katanya sendiri.

Pengumpulan data dalam penelitian ini melalui tes dan wawancara. Subjek diberikan soal pemecahan masalah kontekstual materi aritmatika sosial, setiap langkah penyelesaian ditunjukkan subjek, peneliti mengajukan pertanyaan yang berkaitan kesimpulan subjek tersebut. Beberapa pekan kemudian, subjek diberikan kembali soal pemecahan masalah kontekstual selanjutnya yang serupa dengan soal pemecahan masalah kontekstual yang pertama. Selanjutnya dilakukan wawancara berbasis soal pemecahan masalah kontekstual. Data yang terkumpul berupa hasil tes subjek, dan hasil wawancara yang telah direkam dan dibuatkan transkrip wawancara. Transkrip wawancara yang telah disusun dilengkapi dengan kode. Setelah data terkumpul dilakukan reduksi, abstraksi, transformasi dan pengkategorian tes pertama dan kedua. Selanjutnya menafsirkan data dan menarik kesimpulan penelitian serta memverifikasi kesimpulan. Penarikan kesimpulan dilakukan berdasarkan analisis data tes dan wawancara terhadap subjek dengan cara membandingkan hasil tes dengan hasil wawancara subjek, sehingga dapat ditarik kesimpulan yang benar tentang kemampuan pemecahan masalah yang dimiliki oleh siswa dalam menyelesaikan soal pemecahan masalah kontekstual materi aritmatika sosial.

\section{Hasil Penelitian dan Pembahasan}

Penelitian ini diawali dengan identifikasi gaya belajar siswa dengan memberikan angket gaya belajar yang telah divalidasi oleh ahli. Hasil identifikasi angket gaya belajar siswa disajikan pada tabel berikut:

Tabel 1. Data gaya belajar siswa kelas 7

\begin{tabular}{lll}
\hline \multicolumn{1}{c}{ Gaya Belajar } & Banyak siswa & Persentase \% \\
\hline Visual & 24 & 68,57 \\
Auditorial & 4 & 11,42 \\
Kinestetik & 3 & 8,57 \\
Visual-Auditorial & 3 & 8,57 \\
Visual - Kinestetik & 1 & 2,86 \\
\hline Jumlah & 35 & 100 \\
\hline
\end{tabular}

Sumber: Data primer yang telah diolah (2021)

Berdasarkan tabel, calon subjek yang memenuhi kriteria dari tiap gaya belajar lebih dari satu. Maka dari itu pemilihan subjek berdasarkan pertimbangan guru mata pelajaran matematika yang mengajar pada kelas tersebut dan mengetahui kemampuan siswa dalam menyelesaikan masalah matematika dengan acuan: (1) subjek dapat berkomunikasi dengan baik dalam mengekspresikan hasil pemikirannya; (2) kesediaan subjek untuk berpartisipasi dalam 
pengambilan data selama proses penelitian. Siswa yang ditetapkan sebagai subjek penelitian disajikan pada tabel berikut:

Tabel 2. Daftar subjek penelitian berdasarkan gaya belajar

\begin{tabular}{ccc}
\hline Inisial Subjek & Gaya Belajar & Kode \\
\hline SP & Visual & SV \\
AKA & Auditorial & SA \\
II & Kinestetik & SK \\
\hline
\end{tabular}

Sumber: Data primer yang telah diolah (2021)

Setelah subjek terpilih berdasarkan gaya belajarnya, masing-masing subjek diberi tes masalah matematika kontekstual materi aritmatika sosial. Tujuan pemberian tes adalah untuk mengetahui analisis pemecahan masalah matematika mereka dalam menyelesaikan soal kontekstual materi untung rugi aritmatika social yang tediri dari 2 butir soal dan terdapat 2 pertanyaan dari tiap soal. Setelah menyelesaikan tes pemecahan masalah kontekstual yang diberikan, kemudian dilakukan wawancara terhadap masing masing subjek mengenai pemecahan masalah yang telah mereka kerjakan, dengan tujuan mendapatkan hasil data yang lebih detail tentang pemahaman matematika siswa dalam menyelesaikan soal.

Hasil analisis kemampuan pemecahan masalah kontekstual siswa tipe visual disajikan pada tabel berikut:

Tabel 3. Data valid Kemampuan Pemecahan Masalah Siswa Visual

\begin{tabular}{|c|c|c|c|}
\hline $\begin{array}{c}\text { Tahap } \\
\text { pemecahan } \\
\text { masalah }\end{array}$ & Hasil tes & Hasil wawancara & Kesimpulan \\
\hline $\begin{array}{l}\text { Memahami } \\
\text { masalah }\end{array}$ & $\begin{array}{l}\text { Mampu menentukan apa } \\
\text { yang diketahui dan } \\
\text { ditanyakan dengan benar, } \\
\text { Mampu menjelaskan } \\
\text { kembali masalah dengan } \\
\text { kalimatnya sendiri }\end{array}$ & $\begin{array}{l}\text { Mampu menentukan apa yang } \\
\text { diketahui dan ditanyakan } \\
\text { dengan benar, } \\
\text { Mampu menjelaskan kembali } \\
\text { masalah dengan kalimatnya } \\
\text { sendiri }\end{array}$ & $\begin{array}{l}\text { Mampu menentukan apa } \\
\text { yang diketahui dan } \\
\text { ditanyakan dengan benar, } \\
\text { Mampu menjelaskan } \\
\text { kembali masalah dengan } \\
\text { kalimatnya sendiri }\end{array}$ \\
\hline $\begin{array}{l}\text { Membuat } \\
\text { renacana }\end{array}$ & $\begin{array}{l}\text { Mengurutkan informasi } \\
\text { dengan benar dan rinci } \\
\text { Membuat rencana sesuai } \\
\text { prosedur } \\
\text { mengarahkan ke rolusi } \\
\text { yang tepat dan rumus yang } \\
\text { benar. }\end{array}$ & $\begin{array}{l}\text { Mengurutkan informasi } \\
\text { dengan benar dan rinci, } \\
\text { Membuat rencana sesuai } \\
\text { prosedur yang mengarahkan } \\
\text { ke solusi yang tepat dan rumus } \\
\text { yang benar. }\end{array}$ & $\begin{array}{l}\text { Mengurutkan informasi } \\
\text { dengan benar dan rinci, } \\
\text { Membuat rencana sesuai } \\
\text { prosedur } \\
\text { mengarahkan ke solusi } \\
\text { yang tepat dan rumus yang } \\
\text { benar. }\end{array}$ \\
\hline $\begin{array}{l}\text { Melaksanakan } \\
\text { rencana }\end{array}$ & $\begin{array}{l}\text { Melaksanakan semua } \\
\text { rencana penyelesaian } \\
\text { masalah yang telah dibuat } \\
\text { sebelumnya dengan sangat } \\
\text { baik, } \\
\text { Menyelesaikan semua } \\
\text { proses perhitungan dan } \\
\text { menentukan hasil akhir } \\
\text { persentase keuntungan } \\
\text { dengan benar }\end{array}$ & $\begin{array}{l}\text { Melaksanakan semua rencana } \\
\text { penyelesaian masalah yang } \\
\text { telah dibuat sebelumnya } \\
\text { dengan sangat baik, } \\
\text { Menyelesaikan semua proses } \\
\text { perhitungan dan menentukan } \\
\text { hasil akhir persentase } \\
\text { keuntungan dengan benar }\end{array}$ & $\begin{array}{l}\text { Melaksanakan semua } \\
\text { rencana penyelesaian } \\
\text { masalah yang telah dibuat } \\
\text { sebelumnya dengan sangat } \\
\text { baik, } \\
\text { Menyelesaikan semua } \\
\text { proses perhitungan dan } \\
\text { menentukan hasil akhir } \\
\text { persentase keuntungan } \\
\text { dengan benar }\end{array}$ \\
\hline $\begin{array}{l}\text { Memeriksa } \\
\text { kembali }\end{array}$ & $\begin{array}{l}\text { Membuat kesimpulan dari } \\
\text { yang ditanyakan pada soal } \\
\text { dengan benar }\end{array}$ & $\begin{array}{l}\text { Membuat kesimpulan dari } \\
\text { yang ditanyakan pada soal } \\
\text { dengan benar }\end{array}$ & $\begin{array}{l}\text { Membuat kesimpulan dari } \\
\text { yang ditanyakan pada soal } \\
\text { dengan benar }\end{array}$ \\
\hline
\end{tabular}

Sumber: Data primer yang telah diolah (2021)

Berdasarkan data valid, subjek SV mampu memahami masalah dengan baik. Subjek SV mampu menentukan dengan benar apa yang diketahui dan ditanyakan pada soal pemecahan masalah, dan menjelaskan kembali masalah dengan kalimatnya sendiri. Dalam membuat 
rencana, subjek SV mampu merencanakan pemecahan masalah dengan baik yaitu dengan cara mengurutkan informasi dengan benar dan rinci sesuai prosedur yang mengarahkan ke solusi penyelesaian yang tepat dan rumus yang benar. Subjek SV mampu melaksanakan semua rencana penyelesaian masalah yang telah dibuat sebelumnya dengan sangat baik, menyelesaikan semua proses perhitungan dan menentukan hasil akhir persentase keuntungan dengan benar. Subjek SV mampu memeriksa kembali pekerjaannya dan mampu membuat kesimpulan dari yang ditanyakan pada soal dengan benar.

Hasil Analisis Kemampuan Pemecahan Masalah Kontekstual Siswa Tipe Auditori disajikan pada tabel berikut:

\section{Tabel 4. Data valid Kemampuan Pemecahan Masalah Siswa Auditori}

\begin{tabular}{|c|c|c|c|}
\hline $\begin{array}{c}\text { Tahap } \\
\text { pemecahan } \\
\text { masalah }\end{array}$ & Hasil tes & Hasil wawancara & Kesimpulan \\
\hline $\begin{array}{l}\text { Memahami } \\
\text { masalah }\end{array}$ & $\begin{array}{l}\text { Mampu menentukan apa } \\
\text { yang diketahui dan } \\
\text { ditanyakan dengan benar, } \\
\text { Mampu menjelaskan } \\
\text { kembali masalah dengan } \\
\text { kalimatnya sendiri }\end{array}$ & $\begin{array}{l}\text { Mampu menentukan apa } \\
\text { yang diketahui dan } \\
\text { ditanyakan dengan benar, } \\
\text { Mampu menjelaskan } \\
\text { kembali masalah dengan } \\
\text { kalimatnya sendiri }\end{array}$ & $\begin{array}{l}\text { Mampu menentukan apa } \\
\text { yang diketahui dan } \\
\text { ditanyakan dengan benar, } \\
\text { Mampu menjelaskan } \\
\text { kembali masalah dengan } \\
\text { kalimatnya sendiri }\end{array}$ \\
\hline $\begin{array}{l}\text { Membuat } \\
\text { renacana }\end{array}$ & $\begin{array}{l}\text { Mengurutkan informasi } \\
\text { dengan benar dan rinci, } \\
\text { Membuat rencana sesuai } \\
\text { prosedur } \\
\text { mengarahkan ke solusi } \\
\text { yang tepat dan rumus yang } \\
\text { benar. }\end{array}$ & $\begin{array}{l}\text { Mengurutkan informasi } \\
\text { dengan benar dan rinci, } \\
\text { Membuat rencana sesuai } \\
\text { prosedur } \\
\text { mengarahkan ke solusi } \\
\text { yang tepat dan rumus yang } \\
\text { benar. }\end{array}$ & $\begin{array}{l}\text { Mengurutkan informasi } \\
\text { dengan benar dan rinci, } \\
\text { Membuat rencana sesuai } \\
\text { prosedur yang mengarahkan } \\
\text { ke solusi yang tepat dan } \\
\text { rumus yang benar. }\end{array}$ \\
\hline $\begin{array}{l}\text { Melaksanakan } \\
\text { rencana }\end{array}$ & 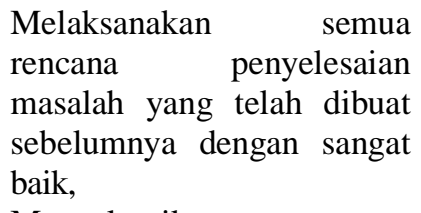 & $\begin{array}{l}\text { Melaksanakan semua } \\
\text { rencana penyelesaian } \\
\text { masalah yang telah dibuat } \\
\text { sebelumnya dengan sangat } \\
\text { baik, }\end{array}$ & $\begin{array}{l}\text { Melaksanakan } r \text { semua } \\
\text { rencana penyelesaian } \\
\text { masalah yang telah dibuat } \\
\text { sebelumnya dengan sangat } \\
\text { baik, }\end{array}$ \\
\hline & $\begin{array}{l}\text { Menyelesaikan } \\
\text { proses perhitungan dan } \\
\text { menentukan hasil akhir } \\
\text { persentase keuntungan } \\
\text { dengan benar }\end{array}$ & $\begin{array}{l}\text { Menyelesaikan semua } \\
\text { proses perhitungan dan } \\
\text { menentukan hasil akhir } \\
\text { persentase keuntungan } \\
\text { dengan benar }\end{array}$ & $\begin{array}{l}\text { Menyelesaikan remua } \\
\text { proses perhitungan dan } \\
\text { menentukan hasil akhir } \\
\text { persentase keuntungan } \\
\text { dengan benar }\end{array}$ \\
\hline $\begin{array}{l}\text { Memeriksa } \\
\text { kembali }\end{array}$ & $\begin{array}{l}\text { F. Membuat } \\
\text { kesimpulan dari yang } \\
\text { ditanyakan pada soal } \\
\text { dengan benar }\end{array}$ & $\begin{array}{l}\text { Membuat kesimpulan } \\
\text { dari yang ditanyakan } \\
\text { pada soal dengan benar }\end{array}$ & $\begin{array}{l}\text { Membuat kesimpulan dari } \\
\text { yang ditanyakan pada soal } \\
\text { dengan benar }\end{array}$ \\
\hline
\end{tabular}

Sumber: Data primer yang telah diolah (2021)

Berdasarkan data valid, subjek SA mampu memahami masalah dengan baik dengan menentukan dengan benar apa yang diketahui dan ditanyakan dalam soal pemecahan masalah, serta menjelaskan kembali dengan kalimatnya sendiri. Dalam membuat rencana, subjek SA mampu membuat rencana dengan baik yaitu dengan mengurutkan informasi dengan benar dan rinci sesuai prosedur yang mengarahkan ke solusi penyelesaian yang tepat dan rumus yang benar. Subjek SA mampu menjelaskan langkah-langkah dengan argumen disetiap langkah yang diambil. Subjek mampu melaksanakan semua rencana penyelesaian masalah yang telah dibuat sebelumnya dengan sangat baik, menyelesaikan semua proses perhitungan dan menentukan hasil akhir persentase keuntungan dengan benar. Subjek SA memeriksa kembali jawqabannya dan mampu membuat kesimpulan dari yang ditanyakan pada soal dengan benar. Subjek SA 
melihat kembali hasil pekerjaannya dengan mengecek informasi yang telah teridentifikasi. Subjek SA dapat menjelaskan cara lain dalam menyelesaikan masalah tersebut.

Tabel 5. Data valid Kemampuan Pemecahan Masalah Siswa Kinestetik

\begin{tabular}{|c|c|c|c|}
\hline $\begin{array}{c}\text { Tahap } \\
\text { pemecahan } \\
\text { masalah }\end{array}$ & Hasil tes & Hasil wawancara & Kesimpulan \\
\hline $\begin{array}{l}\text { Memahami } \\
\text { masalah }\end{array}$ & $\begin{array}{l}\text { Mampu menentukan apa } \\
\text { yang diketahui dan } \\
\text { ditanyakan dengan benar, } \\
\text { Mampu menjelaskan } \\
\text { kembali masalah dengan } \\
\text { kalimatnya sendiri }\end{array}$ & $\begin{array}{l}\text { Mampu menentukan apa } \\
\text { yang diketahui dan } \\
\text { ditanyakan dengan benar, } \\
\text { Mampu menjelaskan } \\
\text { kembali masalah dengan } \\
\text { kalimatnya sendiri }\end{array}$ & $\begin{array}{l}\text { Mampu menentukan apa } \\
\text { yang diketahui dan } \\
\text { ditanyakan dengan benar, } \\
\text { Mampu menjelaskan } \\
\text { kembali masalah dengan } \\
\text { kalimatnya sendiri }\end{array}$ \\
\hline $\begin{array}{l}\text { Membuat } \\
\text { renacana }\end{array}$ & $\begin{array}{l}\text { Tidak mengurutkan } \\
\text { informasi dengan benar, } \\
\text { tidak membuat rencana } \\
\text { penyelesaian }\end{array}$ & $\begin{array}{l}\text { Tidak mengurutkan } \\
\text { informasi dengan benar, } \\
\text { tidak membuat rencana } \\
\text { penyelesaian }\end{array}$ & $\begin{array}{l}\text { Tidak mengurutkan } \\
\text { informasi dengan benar, } \\
\text { tidak membuat rencana } \\
\text { penyelesaian }\end{array}$ \\
\hline $\begin{array}{l}\text { Melaksanakan } \\
\text { rencana }\end{array}$ & $\begin{array}{l}\text { Tidak melaksanakan rencana } \\
\text { penyelesaian, tidak } \\
\text { membuat rencana } \\
\text { penyelesaian sebelumnya, } \\
\text { tidak menyelesaikan proses } \\
\text { perhitungan dan menentukan } \\
\text { hasil akhir persentase } \\
\text { keuntungan dengan benar }\end{array}$ & $\begin{array}{l}\text { Tidak melaksanakan } \\
\text { rencana penyelesaian, } \\
\text { tidak membuat rencana } \\
\text { penyelesaian sebelumnya, } \\
\text { tidak menyelesaikan } \\
\text { proses perhitungan dan } \\
\text { menentukan hasil akhir } \\
\text { persentase keuntungan } \\
\text { dengan benar }\end{array}$ & $\begin{array}{l}\text { Tidak melaksanakan rencana } \\
\text { penyelesaian, tidak } \\
\text { membuat rencana } \\
\text { penyelesaian sebelumnya, } \\
\text { tidak menyelesaikan proses } \\
\text { perhitungan dan menentukan } \\
\text { hasil akhir persentase } \\
\text { keuntungan dengan benar }\end{array}$ \\
\hline $\begin{array}{l}\text { Memeriksa } \\
\text { kembali }\end{array}$ & $\begin{array}{l}\text { Tidak membuat kesimpulan } \\
\text { dari yang ditanyakan pada } \\
\text { soal }\end{array}$ & $\begin{array}{l}\text { Tidak membuat } \\
\text { kesimpulan dari yang } \\
\text { ditanyakan pada soal }\end{array}$ & $\begin{array}{l}\text { Tidak membuat kesimpulan } \\
\text { dari yang ditanyakan pada } \\
\text { soal }\end{array}$ \\
\hline
\end{tabular}

Sumber: Data primer yang telah diolah (2021)

Berdasarkan data valid, subjek SK mampu memahami masalah dengan baik yaitu dengan menentukan dengan benar apa yang diketahui dan ditanyakan dalam soal pemecahan masalah, serta menjelaskan kembali dengan kalimatnya sendiri. Dalam membuat rencana, subjek SK tidak mampu mengurutkan informasi dengan benar dan rinci, serta tidak membuat rencana penyelesaian yang tepat dan rumus yang benar. Subjek SK tidak mampu menjelaskan langkahlangkah penyelesaian masalah. Subjek SK tidak mampu melaksanakan semua rencana penyelesaian masalah karena subjek tidak membuat rencana penyelesaian sebelumnya. Subjek SK tidak dapat menyelesaikan semua proses perhitungan dan menentukan hasil akhir persentase keuntungan. Subjek SK tidak mampu melaksanakan tahap memeriksa kembali dengan tidak membuat kesimpulan dari yang ditanyakan pada soal dengan benar. Subjek SK tidak mampu melaksanakan tahap memeriksa kembali dengan mengecek informasi yang telah teridentifikasi. Subjek SK tidak dapat menjelaskan cara lain dalam menyelesaikan masalah tersebut.

Berdasarkan hasil analisis kemampuan pemecahan masalah disimpulkan bahwa siswa yang memiliki gaya belajar visual mampu memecahkan masalah sebanyak empat tahap pemecahan masalah Polya, Pada tahap memahami masalah, siswa yang memiliki gaya belajar visual, mampu menentukan dengan benar apa yang diketahui dan ditanyakan pada soal dan menjelaskan kembali masalah dengan kalimatnya sendiri. Hal ini sesuai dengan pendapat Boneva \& Mihova (2011) bahwa orang-orang yang memiliki gaya belajar visual memiliki karakteristik salah satunya teliti dan detail. Artinya siswa yang memiliki gaya belajar visual teliti terhadap apa yang dikerjakan serta memahami konsep yang dituliskan dengan menuliskan kembali apa yang diketahui dan ditanyakan.

Pada tahap menyusun rencana, siswa yang memiliki gaya belajar visual mampu mengidentifikasi dan mengurutkan informasi. Hal ini seperti yang dikatakan Boneva \& Mihova 
(2011) bahwa siswa yang memiliki gaya belajar visual merupakan perencana yang baik sehingga mampu membuat rencana penyelesaian dengan baik. Pada tahap melaksanakan rencanan pemecahan masalah, siswa yang memiliki gaya belajar visual mampu melaksanakan semua strategi pemecahan masalah dan menentukan hasil akhir dengan benar.

Pada tahap melihat kembali, siswa yang memiliki gaya belajar visual mampu memeriksa kembali semua informasi dan perhitungan dengan cara mengeceknya satu per satu. Hal ini seperti yang dikatakan oleh Deporter dan Hernacki (2013) bahwa siswa visual merupakan siswa yang teliti sehingga memungkinkan untuk mengecek kembali perhitungan dan informasi yang telah teridentifikasi. Namun beberapa siswa yang memiliki gaya belajar visual tidak semuanya mengecek perhitungan karena merasa yakin dengan jawabannya dan waktu yang diberikan tidak cukup untuk mengecek kembali jawaban.

Siswa yang memiliki gaya belajar auditori mampu memecahkan masalah melalui empat tahap pemecahan masalah Polya. Pada tahap memahami masalah, siswa yang memiliki gaya belajar auditori mampu menentukan apa saja yang diketahui dan ditanyakan pada soal pemecahan masalah dan menjelaskan masalah sesuai dengan kalimatnya sendiri. Subjek SA pada tahap memahami masalah menuliskan kembali soal pada tes tertulis, pada saat wawancara, subjek SA mampu menjelaskan apa yang diketahui dan ditanyakan secara rinci dan menjelaskan masalah dengan kalimat sendiri. Hal ini seperti yang dikemukakan oleh Depoter dan Hernacki (2013) bahwa siswa auditori merasa kesulitan dalam menulis tapi hebat dalam bercerita dan pembicara yang fasih.

Pada tahap membuat rencana, subyek yang memiliki gaya belajar auditori mampu mengidentifikasi dan mengurutkan informasi. Subjek SA mampu mencari konsep terkait dengan materi aritmatika sosial dalam permasalahan sehari-hari. Siswa yang memiliki gaya belajar auditori mampu membuat rencana dengan tepat yaitu dengan merencakan menggunakan konsep pemecahan masalah aritmatika sosial untuk mengerjakan masalah yang diberikan. Namun, beberapa siswa yang memiliki gaya belajar auditori mempunyai masalah dengan pekerjaan yang melibatkan visualisasi. Pada tahap melaksanakan rencana, subjek mampu melaksanakan semua strategi pemecahan masalah. Subjek dapat menuliskan dan menjelaskan penyelesaian masalah dari soal dengan benar, lengkap dan sistematis. Pada tahap melihat kembali, subjek memeriksa kembali dengan mengecek informasi yang telah teridentifikasi dan perhitungan yang terlibat. Subjek juga mampu membuat kesimpulan dari apa yang ditanyakan pada soal dan mengecek jawaban dari awal satu per satu.

Siswa yang memiliki gaya belajar kinestetik hanya mampu melaksanakan dua dari empat tahap pemecahan Polya yaitu tahap memahami masalah dan tahap merencanakan. Pada tahap memahami masalah, siswa yang memiliki gaya belajar kinestetik mampu mengetahui apa saja yang diketahui dan ditanyakan pada masalah dan mampu menjelaskan masalah sesuai dengan kalimat dan bahasa sendiri. Siswa yang memiliki gaya belajar kinestetik menuliskan apa yang diketahui dan ditanyakan dengan menulis soal kembali sesuai dengan teks. Pada saat wawancara, siswa yang memiliki gaya belajar kinestetik mampu menjelaskan apa yang diketahui dan ditanyakan dengan baik dan mampu menjelaskan masalah dengan menggunakan kalimat dan bahasa sendiri. Siswa yang memiliki gaya belajar kinestetik menjelaskan dengan pelan sambil membaca soal dengan menggunakan jari sebagai penunjuk membaca. Hal ini sesuai dengan Deporter dan Hernacki (2013) bahwa sisawa yang memiliki gaya belajar kinestetik berbicara dengan perlahan dan menggunakan jari sebagai penunjuk ketika membaca. Selain itu, menurut Boneva dan Mihova (2011) siswa yang memiliki gaya belajar kinestetik merupakan pengeja yang buruk.

Pada tahap membuat rencana, siswa yang memiliki gaya belajar kinestetik mampu menuliskan langkah penyelesaian masalah namun terdapat banyak kesalahan termasuk tidak menuliskan rumus yang digunakan dalam menyelesaikan masalah. Hal ini karena konsep matematika materi aritmatika yang masih lemah. Pada tahap melaksanakan rencana, siswa 
kinestetik yang memiliki kemampuan pemecahan masalah yang rendah tidak menuliskan penyelesaian masalah dari soal, belum mampu melaksanakan semua strategi selama perhitungan berlangsung. Hal ini disebabkan karena subjek tidak mampu melakukan perencanaan dengan benar sehingga menyebabkan tidak memiliki hasil akhir atau hasil akhir yang tidak tepat. Pada tahap memeriksa kembali, siswa kinestetik tidak menuliskan kesimpulan atau menjawab apa yang ditanyakan dari soal. Hal ini seperti yang dikatakan In'am (2014) yang menyatakan bahwa mayoritas siswa tidak melakukan langkah melihat kembali dengan alasan tidak cukup waktu untuk melakukannya.

\section{Kesimpulan}

Berdasarkan pembahasan hasil penelitian, dapat ditarik beberapa kesimpulan tentang gambaran analisis kemampuan pemecahan masalah kontekstual siswa materi aritmatika dalam menyelesaikan soal aritmatika sosial ditinjau dari gaya belajar berdasarkan tahapan Polya.

1. Kemampuan pemecahan masalah kontekstual siswa dengan gaya belajar tipe visual dalam menyelesaikan soal aritmatika social cukup baik cenderung memenuhi semua indikator kemampuan pemecahan masalah yaitu memahami masalah, membuat rencana penyelesaian masalah, melaksanakan rencana penyelesaian masalah kurang tepat dalam menentukan hasil akhir, memeriksa kembali.

2. Kemampuan pemecahan masalah kontekstual siswa dengan gaya belajar tipe auditori dalam menyelesaikan soal aritmatika sosial memenuhi semua indikator kemampuan pemecahan masalah yaitu memahami masalah, membuat rencana penyelesaian masalah, melaksanakan rencana penyelesaian masalah, memeriksa kembali.

3. Kemampuan pemecahan masalah kontekstual siswa dengan gaya belajar tipe kenestetik dalam menyelesaikan soal aritmatika sosial sangat kurang, hanya memenuhi satu indikator kemampuan pemecahan masalah yaitu memahami masalah.

\section{DAFTAR PUSTAKA}

Alisa, O. N. (2016). Strategi Mental Computation Siswa Bergaya Belajar Random dalam Menyelesaikan Soal Aritmatika Sosial di Mi Ma'arif Sambiroto. Universitas Islam Negeri Sunan Ampel Surabaya.

Asrori, M. (2007). Psikologi Pembelajaran (pertama). Bandung: CV WACANA PRIMA.

Boneva, D. \& Mihova, E. (2011). Dyslexia and additional academic language learning. Bulgaria: Dyslexia Association.

DePorter, Bobbi dan Hernacki, Mike. 2013. Quantum Learning: Membiasakan Belajar Nyaman dan Menyenangkan. Bandung: Kaifa Learning.

In'am, A. (2014). The Implementation of the Polya Method in Solving Euclidean Geometry Problems. International Education Studies; Vol. 7, No. 7; 2014 ISSN 1913-9020 E-ISSN 1913-9039, 151. 
Ma'rufi, \& Yulianti. (2019). Analisis Keterlaksanaan Pendekatan Pemecahan Masalah Pada Materi Bangun Ruang Sisi Datar. Pedagogy: Jurnal Pendidikan Matematika, Vol 4 (2), $71-96$

Minarti, \& Kusrini. (2012). Analisis Tingkat Kemampuan Siswa dalam Memecahkan Masalah Bentuk Soal Cerita Pada Materi Sistem Persamaan Linier Dua Variabel. FMIPA Universitas Negeri Surabaya, (1), 1-8.

Paramitha, N. T. N. H. Y. (2017). Analisis Proses Berpikir Kreatif Dalam Memecahkan Masalah Matematika Materi Aritmatika Sosial Siswa Smp Berkemampuan Tinggi. Jurnal Miitra Pendidikan (JMP Online), 1(10), 983- 994. Retrieved from http://ejurnalmitrapendidikan.com.

Sanjaya, W. (2013). Strategi Pembelajaran Berorientasi Standar Proses Pendidikan. Jakarta: Kencana Prenada.

Santia, I. (2015). Representasi Siswa SMA dalam Memecahkan Masalah Matematika Berdasarkan Gaya Kognitif. Jurnal Ilmiah Pendidikan Matematika, 3(2), 365-381.

Trianto. (2016). Analisis Pemecahan Masalah Aljabar Siswa Kelas Viii Smp Negeri 3 Palu. In Jurnal Elektronik Pendidikan Matematika Tadalako (Vol. 3). Retrieved from http://jurnal.untad.ac.id-/jurnal/index.php/JEPMT/-article/download/7223/581 2. 